\title{
A Study on the Performance of Commercial Banks in Ethiopia
}

\author{
Eneyew Lake Atnafu \\ College of Business and Economics, Department of Accounting and finance, \\ Debre Markos University, Ethiopia
}

\begin{abstract}
This study examines the impact of financial risks on the profitability of commercial banks for a total of eight commercial banks in Ethiopia, covering the period of 2000-2011. To this end, the study adopts a mixed methods research approach by combining documentary analysis and in-depth interviews. The study reviews the financial records of eight commercial banks in Ethiopia and relevant data on macroeconomic factors considered. The findings of the study show that Credit risk and liquidity risk have a negative and statistically significant relationship with banks' profitability. However, the relationship for interest rate risk and foreign exchange rate risk is found to be statistically insignificant. Bank size, capital strength and GDP growth were found to be the major factors determining the volatility of profit in Ethiopian commercial banks. The coefficient estimates of the above mentioned controlled variables were positive and statistically significant at $1 \%$ significance level. The study suggests that focusing in credit risk management and keeping optimal level of liquidity which enables banks to meet their contractual commitments could maximize return on assets Ethiopian commercial banks.
\end{abstract}

Keywords: commercial banks, profitability, financial risks

DOI: $10.7176 /$ RJFA/11-13-04

Publication date:July $31^{\text {st }} 2020$

\section{Introduction}

Profitable and strong banking system stimulates larger financial stability and rises the economy's resilience to adverse macroeconomic shocks. A healthy and sustainable profitability is significant in maintaining the stability of the banking system and for sustainable economic growth in general (Tafri, et al., 2009).

After Ethiopia also undertook a banking reform program in 1994 the banking system in Ethiopia has witnessed a significant expansion. The reform encouraged private banks to enter and expand their operations in the industry. Although such growth has taken place, as indicated in the National Bank of Ethiopia (NBE) 2010/11 annual report the banking system in Ethiopia is underdeveloped. Ethiopia is still one of the most under banked countries in the world with one bank branch serving over 82,000 people and the sector contributing little to GDP (NBE 2011). Ethiopian banks are characterized by operational inefficiency and insufficient competition (Lelissa (2007) and Abera (2012)). Thus these indicate the banking sector inefficiencies. As noted in DemirgucKunt and Huizinga (1999) Bank profitability can be seen as indicator of the (in) efficiency of the banking system. To improve banking sector efficiency it is therefore, worthwhile to identify the main factors which affect banks profitability.

Hence, identification and analysis of the determinants of bank profitability have attracted for many years the interest of academic researchers as well as bank management, supervisors and financial service participants. Both internal and external factors have been affecting the profitability of banks over time. And most studies in the literature find that internal bank characteristics explain a large proportion of banks profitability. Among others Shafiq \& Nasr (2010), Achou and Tenguh (2008), Al- Khouri (2011), Kithinji (2010), Baesens and Gestel (2009), found that internal bank characteristics such as risks explain a large proportion of banks profitability.

In spite of the fact that banks are in the business of taking risk, it should be recognized that an institution need not engage in business in a manner that unnecessarily imposes risk upon it: nor it should absorb risk that can be transferred to other participants.

Thus examining the impact that the financial risks have on the profitability of the commercial banks in Ethiopia is essential for all banks as it enable them to manage those risks effectively. In order to increase the return, banks should know which risk factors have greater effect on profitability.

In light of the above, a lot of research work has so far taken place concerning the issue of determinants of bank profitability. Some earlier studies in the case of Ethiopian banks tried to identify factors contribute for the performance of the banks. However as the review of the literature presented indicated, the previous studies conducted in Ethiopia in relation to this problem area do not incorporate specific risks in their models. Thus to the knowledge of the researcher, there appears to be very limited work on examining the impact of financial risks on profitability of banks. This topic is still relatively under-explored area in the banking literature in Ethiopia. So Conclusion about the impact of financial risks on the banks performance remains ambiguous.

Hence the intent of this proposed study is to examine the impact level of financial risks (credit risk, liquidity risk, interest rate risk and foreign exchange rate risk) on profitability of commercial banks in Ethiopia. 


\section{Statement of the problem}

Banking is a business mostly associated with risk because of its large exposure to uncertainty and huge considerations. Risk management is one of the most important practices to be used especially in banks, for getting assurance about the reliability of the operations and procedures being followed. An efficient risk management system is the need of time. Managing risk is one of the basic tasks to be done, once it has been identified and known.

After the introduction of the reform in 1994 the banking industry in Ethiopia has experienced considerable changes such as entry of new banks in the industry which is expected to increase the competition among the commercial banks. The competition leads the banks to extend huge amounts of credit with the main objective of increasing profitability which may result in non-performing loans. For instance as the NBE's report presented during the review fiscal year 2009/10, deposit mobilized and outstanding loans of the banking system surged by 56.7 and 20.6 percent, respectively. The banking system disbursed fresh loans amounting to Birr 28.9 billion, 13.5 percent higher than last year, despite NBE's credit ceiling. Given lending restrictions imposed by the central bank during the fiscal year 2009/10, the increase in banks' lending was of course not as fast as the growth of deposits but still managed to rise by 21 percent (NBE2009/10).

With the recent development in the banking industry in Ethiopia, all banks are exposed to financial risks. Credit risk, operational risk and liquidity risk are dominant risks in Ethiopian banking industry. The volume of assets and liabilities carried by banks in Ethiopia that cannot be re-priced easily is increasing overtime thereby exposing banks to interest rate risk (NBE 2010).

Risk may have positive or negative outcomes or may simply result in uncertainty. Therefore, risks may be considered to be related to an opportunity or a loss or the presence of uncertainty for an organization. Every risk has its own characteristics that require particular management or analysis. Financial managers should always consider the tradeoff between the amount of risk and return.

The important factor in financial intermediation management is the risk managements. Managing risk is one of the basic tasks to be done, once it has been identified. Risk management as commonly perceived does not mean minimizing risk; rather the goal of risk management is to optimize risk-reward tradeoff. Therefore in order to increase the return, banks should know which risk factors have greater effect on profitability. Theoretically the tradeoff between risk and return is well acknowledged - the higher return comes with higher risk. Therefore in order to increase the return, banks should know which risk factors have greater effect on profitability.

However, to the knowledge of the researcher, no study to date provides a comprehensive analysis of the impact of financial risks on profitability of commercial banks in Ethiopia. Therefore, the deficiencies of the previous studies to be discussed in the next chapter along with the above discussed issues call for the current research.

\section{Broad objective and hypotheses}

The broad objective of this study is to examine the impact of financial risks on profitability of commercial banks in Ethiopia controlling the influence of some selected macro and bank specific variables.

\section{Hypotheses of the study}

In line with the broad objective describe above, the following hypotheses were also formulated for investigation based on theories and past related empirical studies.

Hypothesis 1: Credit risk has significant negative impact on the profitability of the banks.

Hypothesis 2: Liquidity risk has significant negative impact on the profitability of the banks.

Hypothesis 3: Interest rate risk has a significant positive relationship with banks profitability

Hypothesis 4: foreign exchange rate risk has a significant negative relationship with banks' profitability

Hypothesis 5: Bank size has a significant positive relationship with banks' profitability

Hypothesis 6: capital strength has a significant positive relationship with banks' profitability

Hypothesis 7: GDP growth has a significant positive relationship with banks' profitability

Hypothesis 8: Inflation has a significant negative relationship with banks' profitability

\section{Literature review}

\subsection{The Relationship between financial risks and profitability}

Risks are usually defined by the adverse impact on profitability of several distinct sources of uncertainty. It is also commonplace to argue that the expected return on an asset should be positively related to its risk. That is, individuals will hold a risky asset only if its expected return compensates for its risk. Both the Capital asset pricing model (CAPM) developed in the early 1960s and Arbitrage pricing theory (APT) imply a positive relationship between expected return and risk. Even, the APT views risk more generally than just the standardized covariance or beta of a security with the market portfolio. The relevant risk of an individual stock, which is called its beta coefficient, is defined under the CAPM as the amount of risk that the stock contributes to the market portfolio. And the CAPM states that the expected returns on stocks should be related only to beta, 
which represents Market risk or systematic risk; it is the risk that remains after diversification. Standard asset pricing models also imply that arbitrage should ensure that riskier assets are remunerated with higher returns.

The basic concepts of the CAPM were developed specifically for common stocks, and fundamental assumptions for the positive risk-return tradeoff are that investors are risk averse, and thus investors demand compensation for bearing risk, Any investor can lend and borrow an unlimited amount at the risk free rate of interest, There are no taxes or transaction costs, and All investors have access to the same information at the same time. However, In reality, every investor has a credit limit, and Real financial products are subject both to taxes and transaction costs, and taking these into account will alter the CAPM's trade-off assumption of higher risk for higher return.

An alternative to the CAPM, called the arbitrage pricing theory (APT), has been developed more recently. The differences between the two models stem from the APT's treatment of interrelationship among the returns on securities. The APT assumes that returns on securities are generated by a number of industry wide and market wide factors. Correlation between a pair of securities occurs when these two securities are affected by the same factor or factors. By disparity, though the CAPM allows correlation among securities, it does not specify the underlying factors causing the correlation (Wang et al., 2012).

CAPM is widely used by analysts, investors, and corporations. However, despite the CAPM's intuitive appeal, a number of studies have raised concerns about its validity. In particular, a study by Fama and French doubt on the CAPM. Fama and French (1992) found two variables that are consistently related to stock returns: (1) the firm's size and (2) its market/book ratio. After adjusting for other factors, they found that smaller firms have provided relatively high returns, and that returns are relatively high on stocks with low market/book ratios. At the same time, and contrary to the CAPM, they found no relationship between a stock's beta and its return (Jaffe 2003).

The main source of revenue or main sources of profit of banks came from lending money to their customers. Which means Risk-taking is an inherent element of banking and, indeed, profits are in part the reward for successful risk taking. In contrary, excessive, poorly managed risk can lead to distresses and failures of banks. The prime reason to adopt risk management practices is to avoid the probable failure in future. But, in realistic terms, risk management is clearly not free of cost. In fact, it is expensive in both resources and in institutional disruption. But the cost of delaying or avoiding proper risk management can lead to some adverse results, like failure of a bank and possibly failure of a banking system (Meyer, 2000).

Financial risks in banking associated with the provision of banking services are risks related to the financial operation of a business, such as credit risk, liquidity risk, interest rate risk and currency risk.

\subsection{Empirical review}

There are prior studies conducted in different countries which are related to the topic/problem of this study. In order to show the research gap and justify the importance of this study the following section presents review of the empirical evidence.

A study made by Tafri et al. (2011) examined the relationship between financial risks (credit risk, interest rate risk and liquidity risks.) and profitability of the conventional and Islamic banks in Malaysia for the period between 1996 and 2005. They used panel data regression analysis of Generalized Least Squares of fixed effects and random effects models and found that credit risk has a significant impact on profitability of the conventional as well as the Islamic banks. The relationship between interest rate risk and ROE were found to be weakly significant for the conventional banks and insignificant for the Islamic banks. The effect of interest rate risk on ROA is significant for the conventional banks. And also they found liquidity risk to have an insignificant impact on profitability.

Imad et al. (2011) examined that the credit risk is associated with significant inverse relationship with profitability in Jordan, thus, increased exposure to credit risk in Jordanian banking sector lowers profits.

Akhtar et al. (2011) studied factors influencing the profitability of Conventional Banks of Pakistan. They intend to study the bank-specific determinants of conventional banks in Pakistan to highlight and identify the significant factors that are influencing on bank's profitability. They reported none performing loans ratio is found to have negative and significant effect on the profitability of commercial banks.

Olweny \& Shipho (2011) examined the effects of banking sector factors on the profitability of commercial banks in Kenya. They adopted an explanatory approach by using panel data research design. Annual financial statements of 38 Kenyan commercial banks from 2002 to 2008 were obtained were used for the analysis purpose. The data was analyzed using multiple linear regressions method. The results of the analysis showed that all the bank specific factors had a statistically significant impact on profitability, while none of the market factors had a significant impact.

Al-Khouri (2011) also investigated the impact of bank's specific risk characteristics, and the overall banking environment on the performance of 43 commercial banks operating in the 6 of the Gulf Cooperation Council (GCC) countries over the period 1998-2008 by using fixed effect regression analysis. The results 
showed that credit risk, liquidity risk and capital risk are the major risk factors that affect bank performance when profitability is measured by return on assets and the only risk that affected the profitability as measured by return on equity is the liquidity risk.

On the other hand Kithinji (2010) determined the relationship between the credit risk management and profitability of commercial banks in Kenya and the findings reveal that the bulk of the profits of commercial banks is not influenced by the amount of credit and nonperforming loans suggesting that other variables other than credit and nonperforming loans impact on profits. Commercial banks that are keen on making high profits should concentrate on other factors other than focusing more on amount of credit and nonperforming loans.

Bordeleau and Graham (2010) studied the impact of liquidity on bank profitability. They present empirical evidence regarding the relationship between liquid asset holdings and profitability for a panel Canadian and U.S. banks over the period of 1997 to 2009. The result suggest that a nonlinear relationship exists, whereby profitability is improved for banks that hold some liquid assets, however, there is a point beyond which holding further liquid assets diminishes a banks' profitability, all else equal.

Valentina et al. (2009) measure credit risk using the ratio of loans to deposits and short-term funding since this provide a forward-looking measure of bank exposure to default and asset quality deterioration. Given that the portfolio of outstanding loans is non tradable, credit risk is modeled as a predetermined variable in their specification. Based on standard asset pricing arguments, they expect a positive association between profits and bank risk and found that credit risk has a positive and significant effect on profitability. This suggests that riskaverse shareholders target risk adjusted returns and seek larger earnings to compensate higher credit risk.

Shen et al. (2009) carried out a study on twelve advanced economies commercial banks over the period 1994-2006 with the title Bank liquidity risk and performance. The study investigates the causes of liquidity risk and the relationship between bank liquidity risk and performance for those banks with the specified period and they find that liquidity risk is the endogenous determinant of bank performance. The causes of liquidity risk include components of liquid assets and dependence on external funding, supervisory and regulatory factors and macroeconomic factors

Pasiouras \& Kosmidou (2007) examined the effects of internal and external variables on profitability, including the capital ratio, cost to income ratio, loans to customers and short-term funding, bank size, inflation, GDP growth, concentration, and three determinants reflecting the development of banking and stock markets on bank returns for 584 domestic and foreign commercial banks in the 15 developed European Union countries over the period 1995-2001. The effects of all variables are found to be significant, regardless of bank.

Athanasoglou et al. (2005) examined Bank-specific, Industry specific and macroeconomic determinants of bank Profitability, bank of Greece and as expected, credit risk is negatively and significantly related to bank profitability. This shows that in the Greek banking system managers, attempting to maximize profits, seem to have adopted a risk-averse strategy, mainly through policies that improve screening and monitoring credit risk.

Zhang and Epperson (2004) conducted their paper on "Profitability and risk of U.S. agricultural banks" The researcher believed that Study of profitability and risk of agricultural banks is very important in assessing the ability to adequately finance agricultural production and rural development. A recursive system of profitability and risk equations is estimated to compare the performance of agricultural with nonagricultural banks and to identify factors which affect performance. A linear regression model which measures risk-adjusted profitability confirms the results from the recursive system. The finding of the researcher was agricultural banks perform better than nonagricultural counterparts on average even after controlling for risks and other factors. Further, offbalance-sheet business is found to be negatively related to the risk-adjusted profitability of agricultural banks.

Shamsuddin (2009) conducted a study with the topic Interest rate and foreign exchange risk exposures of Australian Banks. This study estimates systematic risk exposure of publicly listed Australian banks with respect to market, interest rate and foreign exchange rate using a GARCH-in-Mean model. Not surprisingly, the results suggest that nearly all banks exhibit varying degrees of market risk exposure. However, stock returns of large banks are highly sensitive to interest rate changes, while most small banks are almost immune to both interest and exchange rate changes.

Delport and $\mathrm{Li}$ (2009) also conduct study with the purpose of evaluating the effect of exchange rates movement on fourteen listed Chinese banks' equity returns, by using the Arbitrage Pricing Theory Model. In particular, this study analyses the three foreign currencies holding the largest trading position with China, namely the Euro, US Dollar, and Japanese Yen. This empirical study finds that Chinese banks are on average most sensitive to exchange-rate movements with regards to Japanese yen.

Popov and Stutzmann (2003) investigated how two Swiss companies manage their foreign exchange risk and examined that forward and netting are the most used instruments and transaction exposure is the most managed foreign exchange risk. And translation and economic exposures are not well identified and managed mainly because firms believe it is unnecessary or too complex. And also they observed that firms hedge their exposure but never fully due to high cost of hedging.

Hedging allows the commercial banks to manage foreign exchange risk but hedging itself poses additional 
risk to bank. Gandhi (2006) mentioned that currency derivatives like currency futures, currency forwards, currency swaps and currency options help in hedging foreign exchange risk of firms and other ways of hedging including off-setting positions against the underlying assets and money markets are themselves risky. Hedging and hedging right are two different things. If the hedging is not done properly in the right way, it itself can become a serious source of risk and have potential to pose a serious financial loss to the firm.

In Ethiopian case also study was conducted by Tefera (2011) with the topic 'Credit risk management and profitability of Commercial Banks in Ethiopia.' He used nonperforming loan ratio and capital adequacy ratio as a proxy for credit risk and the result showed that both proxies has a negative impact on profitability of commercial banks in Ethiopia.

Kapur and Gualu (2011) investigated the impact of macroeconomic factors, financial system, banking sector variables and bank-specific characteristics on Ethiopian commercial banks' profits measured using return on assets (ROA) measure of profit. They examined that nonperforming loans and advances to the total loans and advances ratio (NPL) has negative and significant impact on Ethiopian banks profit.

Damena (2011) conducted study with the title "Determinants of commercial banks profitability: empirical study on Ethiopian Commercial Banks", with the aim to examine the impact of bank-specific, industry-specific and macroeconomic determinants of Ethiopian commercial banks profitability applying the balanced panel data of seven Ethiopian commercial banks that covers the period 2001- 2010. This study showed that all bankspecific determinants, with the exception of saving deposit, significantly affect commercial banks profitability in Ethiopia. He examined as credit risk is the main significant factor which challenges the profitability of banks in Ethiopia.

Abera (2012) besides examined the bank-specific, industry-specific and macro-economic factors affecting bank profitability for a total of eight commercial banks in Ethiopia, covering the period of 2000-2011 Using a mixed methods research approach and found that capital strength, income diversification, bank size and gross domestic product have statistically significant positive relationship with banks' profitability and variables like operational efficiency and asset quality have a negative and statistically significant relationship with banks' profitability. And also the relationship for liquidity risk measured with a ratio of liquid assets to total assets, concentration and inflation is found to be statistically insignificant.

NBE, 2009, Results of banking sector risk management survey suggests existence of some positive steps taken so far by banks to strengthen their risk management practices. The survey revealed that credit, operational and liquidity risks have been dominant risks over the last two years, and will continue to be key risks over the next five years.

Although a very limited number of studies such as Kapur and Gualu (2011), Damena (2011), and Abera (2012), conducted in Ethiopia appear to include credit risk as explanatory variables for commercial banks profitability, this relationship is not the focus of those papers and credit risk is generally included as a control variable in these studies with very limited discussion around the estimated parameter. Abera (2011) also included liquidity as explanatory variable for commercial banks profitability and found its impact insignificant and point to a need for further investigation in this regard. The study conducted by Tefera (2011) also tried to examine only the impact of credit risk on profitability of commercial banks in Ethiopia using quantitative methods.

Therefore information about the impact of financial risks on the banks performance remains ambiguous. This study therefore, will be an attempt to address this gap of information on Ethiopian commercial banking sector. Then, the intent in this proposed study is to measure the impact level of financial risks on profitability of commercial banks in Ethiopia using mixed method approach.

\section{Research design and methodology}

\subsection{Variables selection}

\subsubsection{Dependent Variables}

The dependent variable in this study is profitability. For this study, the measure of profitability employed is return on assets (ROA) which reflects the ability of a bank's management to generate profit from the bank's assets and is defined as the ratio of net income to average of total assets. ROA is used as the key proxy for bank profitability, instead of the alternative return on equity (ROE), because an analysis of ROE disregards financial leverage and the risks associated with it. And also ROA is a more comprehensive measure of profitability and, second, it is widely used in the literature, which allows comparison with previous studies in Ethiopia or other countries. 
5.1.2. Independent Variables and hypotheses

Table 5.1 Descriptions of the variables and their expected relationship

\begin{tabular}{|l|l|l|l|l|}
\hline & Variables & Measure & Notation & $\begin{array}{l}\text { Expected } \\
\text { Sign }\end{array}$ \\
\hline $\begin{array}{l}\text { Dependant } \\
\text { variable }\end{array}$ & Profitability & Net income/total assets & ROA & NA \\
\hline $\begin{array}{l}\text { Independent } \\
\text { variables }\end{array}$ & Credit risk & Non-performing loans/total loans & CR & - \\
\cline { 2 - 5 } & Liquidity risk & Liquid assets/ deposits and borrowings & LIQ & - \\
\cline { 2 - 5 } & Interest rate risk & $\begin{array}{l}\text { Rate sensitive Assets-Rate sensitive } \\
\text { liabilities/total capital }\end{array}$ & IRR & + \\
\cline { 2 - 5 } & $\begin{array}{l}\text { Foreign exchange } \\
\text { rate risk }\end{array}$ & $\begin{array}{l}\text { Exchange rate } \\
\text { Volatility }\end{array}$ & FORX & - \\
\cline { 2 - 5 } & Capital & Equity / total Asset & CAP & + \\
\cline { 2 - 5 } & Bank Size & Natural log Total Asset & SIZE & + \\
\cline { 2 - 4 } & Growth & GDP growth & GDP & + \\
\cline { 2 - 4 } & Inflation & The annual inflation rate & $?$ \\
\hline
\end{tabular}

Survey design (structured review of documents) is applied for this study. Survey was carried out by means of structured document review. The data related to a documentary analysis which is necessary to undertake this study was gathered from the audited financial statements of the banks and NBE for twelve consecutive years (2000-2011) and for some controlled macroeconomic variables in this study the researcher used data taken from NBE and Ethiopian Ministry of Finance and Economic Development (MoFED).

\subsection{Sampling design}

The population of the study is all commercial banks registered by NBE. There are 18 banks operating in the Ethiopian banking sectors. In this study, two criteria are used to determine the study sample. The first criterion is the nature of the bank. In the study, only commercial banks registered by NBE and under operation in the country currently will be included. The main reason to include only commercial banks is to ensure that the econometric estimations are robust; it is preferable to work on a homogeneous sample. Availability of data is the second criteria, to this the study consider only banks that have data for the years 2000 to 2011 . Therefore, based on the above two criterion only eight banks were included in the study from the total banks operating in the Ethiopian banking sectors. The eight commercial banks included in the study are, Awash International Bank (AIB), Bank of Abyssinia, commercial bank of ethiopia (CBE), Construction and Business Bank (CBB), Dashen Bank (DB), Nib International Bank (NIB), United Bank (UB), Wegagen Bank (WB) .

\subsection{Data analyzing methods}

The study was done primarily based on panel data, which was collected through structured document review. In this study, a panel data set which was employed comprises of 8 banks for which the same variables is collected annually for twelve years. Thus this pooled data contains a total of 96 observations.

Thus, the collected panel data was analyzed using descriptive statistics, correlations matrix and multiple linear regression analysis. Therefore, in order to test the hypothesis of this study and to determine the relative importance of each independent variable in influencing profitability of the commercial banks in Ethiopia multiple linear regression analysis was done. Accordingly, a two step multiple linear regression equations were run. In the first step (general) regression equation, all the proposed independent variables (i.e., CR, LIQ, IRR, FORX, SIZE, CAP, INFL and GDP) were regressed with respect to the dependent variable (ROA). Whereas, in the second step only the significant variables that were found from the first step regression equation were regressed to investigate there effect on ROA of Ethiopian commercial banks. The multiple linear regressions model was conducted by the ordinary listing square (OLS) method.

The current study used econometric model which is specified as follows:

PROFITABILITY $=$ F (RISKS, BANK, MACRO)

RISK represents the four financial risks of the banks namely credit risk, liquidity risk, interest rate risk and foreign exchange rate risk while MACRO and BANK are the control variables which denotes a set of macroeconomic variables reflecting the state of the economy and bank specific variables respectively.

Specifically the model is:

ROAit $=\beta 0+\beta 1$ CRit $+\beta 2$ IRRit $+\beta 3$ LIQit $+\beta 4$ FORXit $+\beta 5$ SIZEit $+\beta 6$ CAPit $+\beta 7$ GDPit $+\beta 8$ INFLit $+\mu$ it

Where

ROA it $=$ Return on Assets of bank $\mathrm{i}$ for year $\mathrm{t}$

$\mathrm{CR}$ it $=$ Credit Risk of bank i for year $\mathrm{t}$

IRR it= Interest Rate Risk of bank i for year $t$ 
LIQ it = Liquidity risk of bank i for year $\mathrm{t}$

FORX it $=$ Foreign exchange rate risk of bank $\mathrm{i}$ for year $\mathrm{t}$

SIZE it $=$ Log of Total Assets of bank i for year $t$

CAP it= Bank Capitalization of bank i for year $t$

GDP $\mathrm{t}=$ GDP Growth Rate for year $\mathrm{t}$

$\mathrm{INFLit}=$ Inflation growth rate for year $\mathrm{t}$

$\mathrm{Bi}=$ Coefficients of the variables

$\mu$ it $=$ Error term

The regression analysis is done using Econometric/statistical software package Eviews 6 software.

There are basic assumptions of Classical Linear Regression Model (CLRM) and if the assumptions hold true, then the estimators determined by OLS will have a number of desirable properties, and are known as Best Linear Unbiased Estimators(Brooks 2008). Therefore, diagnostic tests are performed to ensure whether the assumptions of the CLRM are violated or not in the model.

\section{Results}

\subsection{Descriptive statistics}

Table 6.1 presents the outcomes of the descriptive statistics for main variables involved in the econometrics model of this study. The total number of observation for each variable was 96 (i.e., data for 8 banks for the period from the year 2000 to 2012). Key figures, including mean, median, standard deviation, minimum and maximum value were reported. This was generated to give overall description about data used in the model and served as data screening tool to spot unreasonable figure.

Table 6.1: Summary of descriptive statistics for dependent and independent variables

\begin{tabular}{|l|l|l|l|l|l|l|}
\hline Variables & Observations & Mean & Median & Max & Min & Std. Dev. \\
\hline ROA & 96 & 0.032 & 0.035 & 0.057 & 0.006 & 0.012 \\
\hline CR & 96 & 0.133 & 0.087 & 0.535 & 0.000 & 0.118 \\
\hline LIQ & 96 & 0.506 & 0.483 & 1.115 & 0.273 & 0.144 \\
\hline IRR & 96 & -0.900 & -0.580 & 3.955 & -8.668 & 1.934 \\
\hline FORX & 96 & 3.63 & 3.71 & 9.34 & 0.21 & 3.011 \\
\hline SIZE & 96 & 21.797 & 21.679 & 25.462 & 18.778 & 1.365 \\
\hline GDP & 96 & 0.086 & 0.108 & 0.126 & -0.021 & 0.045 \\
\hline CAP & 96 & 0.116 & 0.110 & 0.294 & 0.037 & 0.048 \\
\hline INFL & 96 & 0.107 & 0.090 & 0.364 & -0.106 & 0.118 \\
\hline
\end{tabular}

Note: Return on asset (ROA), Credit risk (CR), Liquidity risk (LIQ), Interest rate risk (IRR), foreign exchange rate risk (FORX), Size (SIZE), Capital (CAP), Inflation (INFL) and Growth domestic product (GDP)

Source: Financial statements of banks, MoFED reports and own computation

As can be seen from table 6.1 , for the total sample, the mean of ROA was $3.2 \%$ with a minimum of $0.6 \%$ and a maximum of $5.7 \%$. This indicated that, Ethiopian commercial banks that were considered in this study were earned an average of 3.2 cents of profit before tax for a single birr invested in their assets. More specifically, the most profitable bank among the sampled banks earned 5.7 cents of profit before tax for a single birr invested in the assets of the bank. On the other hand, the least profitable bank of the sampled banks earned 0.6 cents of profit before tax for each birr invested in the assets of the bank. The standard deviation statistics for ROA was 0.012 which indicates that the profitability variation between the selected banks was very small.

Regarding the independent variables of the model there are some interesting statistics that have to be mentioned. For instance, the descriptive statistic of exchange rate risk which was measured by exchange rate volatility has shown the highest standard deviation (3.011). The result indicates the existence of relatively higher volatility of Ethiopian birr in exchange with U.S dollar for the period under consideration. The size of banks which was measured by natural log of total asset also revealed the highest standard deviation (1.365). This indicates the existence of high variation among ECBs in terms of their size. On the other hand, the mean value of interest rate risk which was measured by ratio of the gap between rate sensitive assets and rate sensitive liabilities capital was -0.90 with a minimum of -8.67 and a maximum of 3.95 . This implies that, on average, Ethiopian commercial banks had been liability sensitive over the period under consideration.

Another interesting observation was the equity-to-asset ratio of banks which indicated by the range between $29.4 \%$ and $3.7 \%$. The average equity-to-asset ratio of banks was $11.6 \%$, which was considerably above the statutory requirement of $8 \%$ set by NBE based on Basel II recommendation. The standard deviation statistics was 0.048 which shows the existence of relatively higher variation of equity to asset ratio between the selected banks compared to the variation in ROA. On the other hand, the outputs of the descriptive statistics indicate that, the average ratio of liquid assets to deposits and liabilities was $50.6 \%$, with a minimum of $27.3 \%$ and a maximum of $111.5 \%$. This means despite the inverse relationship that exists between liquidity and profitability, 
the liquidity measure indicates that the Ethiopian commercial banks have, on average, a higher liquidity position which was somewhat higher than the statutory requirement of $20 \%$ for the last twelve years.

In addition, the mean of CR (measured by the ratio of nonperforming loans to total loans) was $13.3 \%$ with a minimum of $0.86 \%$ and a maximum of $53.5 \%$. This indicates that, from the total loans that ECBs disbursed, an average of $13.3 \%$ were being default or uncollected over the sample period. The disparity between the minimum $0.86 \%$ and the maximum $53.5 \%$ of NPLs indicate the margin that CR ratio of ECBs ranged over the sample period. The standard deviation (0.118) of CR also shows the existence of high variation among ECBs in terms their loan recovering capacity as compared to other variables like ROA. On the other hand, the mean real GDP growth in Ethiopia for the last twelve years was $0.086(8.6 \%)$, with a maximum of $12.6 \%$ and a minimum of $2.1 \%$. The standard deviation was 0.045 ; this implies that economic growth in Ethiopia during the period of 2000 to 2011 remains reasonable stable and the result was more or less in agreement with the government's report regarding economic growth. The other macro-economic variable employed in this study was INFL, had somewhat a higher standard deviation (0.118) compared to GDP; this implies that inflation rate in Ethiopia during the study period remains somewhat unstable.

\subsection{Test results for the classical linear regression model assumptions Test for Hetroscedasticity}

To test for the presence of heteroscedasticity, the popular white test was employed (Brooks 2008). As shown in table 6.2, both the F-statistic and Chi-Square versions of the test statistic gave the same conclusion that there is no proof for the presence of heteroscedasticity in this particular study, since the p-values were significantly in excess of 0.05 . The third version of the test statistic, 'Scaled explained SS' also gave the same conclusion that there is no evidence for the presence of heteroscedasticity problem, since the p-value was considerably in excess of 0.05 . Therefore, the null hypothes that the variance of the errors is constant (homoscedasticity) should not be rejected.

Table 6.2 Heteroskedasticity Test: White

\begin{tabular}{llll}
\hline \hline F-statistic & 1.602178 & Prob. F(44,51) & 0.0562 \\
Obs*R-squared & 55.70232 & Prob. Chi-Square(44) & 0.1110 \\
Scaled explained SS & 40.86005 & Prob. Chi-Square(44) & 0.6070 \\
\hline \hline
\end{tabular}

Source: Financial statements of banks, MoFED reports and own computation

Test for Autocorrelation

As noted in Brooks (2008) this is an assumption that is assumed the errors are uncorrelated with one another. As mentioned in the previous chapter to empirically examine the impact of financial risks on the profitability of Ethiopia commercial banks 96 observations and eight regressors along with an intercept term were used in the model. Therefore, the relevant critical values for 96 observations and 8 regressors in DurbinWatson test statistic table have shown an upper critical value (dU) of 1.715 and a lower critical value (dL) of 1.358 and $4-\mathrm{dU}=4-1.715=2.285 ; 4-\mathrm{dL}=4-1.358=2.642$. As shown in table 6.3, the Durbin-Watson test statistic of this study is 1.687 which is clearly between the lower limit $(\mathrm{dL})$ which is 1.358 and the upper limit which is 1.715 and thus the null hypothesis of no autocorrelation is neither rejected nor not rejected.

Table 6.3 Autocorrelation Test: Durbin Watson

\begin{tabular}{|l|l|}
\hline Variables & DW test static result \\
\hline All bank-specific \& macro-Economic & 1.687 \\
\hline
\end{tabular}

Source: Financial statements of banks, MoFED reports and own computation

Test for normality

In this study, the normality of the data was checked with the popular Bera-Jarque test statistic (Brooks 2008). According to Bera-Jarque test statistic, normally distributed data is not skewed and has a coefficient kurtosis of 3 . As shown in figure 6.1, the coefficient kurtosis(3.06) of the data in this particular study was very much closer to 3 , and the Bera-Jarque statistic had a P-value of 0.5112 implying that there was no evidence for the presence of abnormality in the data. Thus, the null hypothesis that the data is normally distributed should not be rejected since the p-value was considerably in excess of 0.05 and the coefficient of kurtosis very much closer to 3. 
Figure 6.1 Normality test for residuals: Bera-Jarque

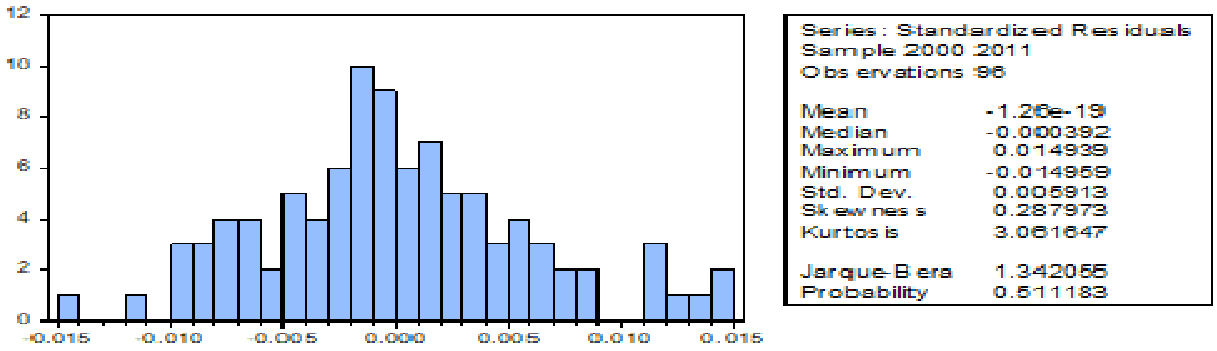

Source: Financial statements of banks, MoFED reports and own computation

Test for model misspecification error

So as to ensure the reliability and the validity of the model, Ramsey reset test (model misspecification error test) was conducted. As shown in table 6.4, both the F-statistic and Log likelihood ratio of the test statistic gave the same conclusion that there is no evidence for the presence of model misspecification error. There is no apparent non-linearity in the regression equation of this particular study, since the p-values were considerably in excess of 0.05 . Therefore, the null hypothesis that the models functional form is appropriate should not be rejected.

Table 6.4. Ramsey RESET Test:

\begin{tabular}{llll}
\hline \hline F-statistic & 0.207373 & Prob. F(1,86) & 0.6500 \\
Log likelihood ratio & 0.231208 & Prob. Chi-Square(1) & 0.6306 \\
\hline \hline
\end{tabular}

Source: Financial statements of banks, MoFED reports and own computation

In general based on diagnostic tests of the CLRM assumptions presented in the above sections, it can be concluded that both the data and the model are free from major threat of misspecifications (diagnostic) problems.

\subsection{Results of Regression Analysis}

There are broadly two classes of panel estimator approaches that can be employed in financial research: fixed effects models (FEM) and random effects models (REM) (Brooks 2008). The general accepted way of choosing between fixed and random effects is running a Hausman test. To conduct a Hausman test the number of cross section should be greater than the number of coefficients to be estimated. But, in this study the numbers of coefficients are greater than the number of cross sections so it is not possible to conduct a Hausman test.

Moreover according to Gujarati (2004), if $\mathrm{T}$ (the number of time series data) is large and $\mathrm{N}$ (the number of cross-sectional units) is small, there is likely to be little difference in the values of the parameters estimated by fixed effect model/FEM and random effect model/REM. Also according to Brooks (2008) and Verbeek (2004), the REM is more appropriate when the entities in the sample can be thought of as having been randomly selected from the population, but a FEM is more plausible when the entities in the sample effectively constitute the entire population/sample frame. Since the number of time series (i.e. 12 year) is greater than the number of crosssectional units (i.e. 8 commercial banks), and the sample for this study was not selected randomly and equals to the sample frame FEM is considered as appropriate for this study. Thus, also considering its computational convenience a fixed cross-sectional effect is specified in the estimation in this study.

The estimation result of the operational panel regression model used in this study is presented in table 6.5. The R-squared statistics and the adjusted-R squared statistics of the model were $76.35 \%$ and $71.91 \%$ respectively. The adjusted- $\mathrm{R} 2$ of this study indicates that, $71.91 \%$ of the variation on the dependent variable (ROA) was explained by the changes in the independent variables. In other words, the change in credit risk, foreign exchange risk, interest rate risk, liquidity risk, equity to total asset ratio, size of a bank, gross domestic product, and inflation rate collectively explain $71.91 \%$ of the changes in ROA. The remaining $28.09 \%$ of changes was explained by other factors which are not included in the econometrics model of this study. Nevertheless based on the result of the regression analysis it can be concluded that, all the independent variables used in this study collectively, were good explanatory variables of profitability in Ethiopian commercial banks (ECBs). Hence the null hypothesis of F-statistic (the overall test of significance) that the R2 is equal to zero was rejected at $1 \%$ significance level $(\mathrm{p}$-value $=0.0)$, which enhanced the reliability and validity of the model. 
Table 6.5. First Step (General) Regression Results

\begin{tabular}{lllll}
\hline \hline Variable & Coefficient & Std. Error & t-Statistic & Prob. \\
\hline \hline C & -0.130218 & 0.029361 & -4.435017 & 0.0000 \\
CR & -0.027858 & 0.009267 & -3.006176 & $0.0035^{*}$ \\
LIQ & -0.016752 & 0.005744 & -2.916247 & $0.0046^{*}$ \\
IRR & $-8.77 \mathrm{E}-05$ & 0.000672 & -0.130619 & 0.8964 \\
FORX & $9.22 \mathrm{E}-06$ & 0.000299 & 0.030853 & 0.9755 \\
CAP & 0.147610 & 0.026728 & 5.522620 & $0.0000^{*}$ \\
SIZE & 0.006931 & 0.001350 & 5.135458 & $0.0000^{*}$ \\
GDP & 0.078192 & 0.021374 & 3.658321 & $0.0005^{*}$ \\
INFL & -0.003115 & 0.008127 & -0.383236 & 0.7026 \\
\hline \hline R-squared & 0.763450 & Durbin-Watson stat & 1.686658 \\
Adjusted R-squared & 0.719096 & & \\
F-statistic & 17.21294 & & \\
Prob(F-statistic) & 0.000000 & & \\
\hline \hline
\end{tabular}

* denote significance at $1 \%$ level.

Source: Financial statements of banks, MoFED reports and own computation

As shown in table 6.5, the coefficient estimate of real GDP growth and capital (equity to total asset ratio) were positive and statistically significant at $1 \%$ significance level. The coefficient estimates of the aforementioned variables were 0.0782 and 0.148 indicating the existence of strong positive relationship between ROA and the above mentioned independent variables. In addition, the coefficient estimate of bank size was positive that implying a direct association with ROA. The association was significant at $1 \%$ significance level. On the other hand, the coefficient estimates of credit risk and liquidity risk were negative and statistically significant at $1 \%$ significance level. The coefficient estimate of foreign exchange rate risk was positive but it was statistically insignificant. In addition, the coefficient estimates of inflation and interest risk have shown a negative association with ROA. The inverse association indicated that, an increase on those variables would decrease the profitability (ROA) of Ethiopian commercial banks. However, the association was not statistically significant. That means, the importance of the abovementioned variables in explaining the variation of profitability in Ethiopian commercial banks was statistically inconsiderable.

As mentioned earlier only the variables CR, LIQ, CAP, SIZE, and GDP that were found significant in the first step regression analysis were regressed once again in order to ensure the reliability and the consistency of the first step regression results both in terms of the coefficient estimates and the level of significance. Table 6.6 shows the second step multiple regression results in which the insignificant variables were dropout. Comparing the results of the two regression analysis, major differences were not found in R-squared statistics, adjusted-R squared statistics and Durbin-Watson stat in both regression results. The R-squared statistics and adjusted-R squared in the second regression were $76.28 \%$ and $72.85 \%$ respectively. In addition, significant variables that were found in the first step regression were remained significant with the same significance level in the second step regression. Moreover, the sign and the magnitude of coefficient estimates in both the first and second step regression were almost similar.

Table 6.6 Second Step Regression Results

\begin{tabular}{|c|c|c|c|c|}
\hline Variable & Coefficient & Std. Error & t-Statistic & Prob. \\
\hline $\mathrm{C}$ & -0.127610 & 0.022792 & -5.598939 & 0.0000 \\
\hline CR & -0.027196 & 0.008700 & -3.125818 & $0.0024 *$ \\
\hline LIQ & -0.016849 & 0.005269 & -3.197686 & $0.0020 *$ \\
\hline CAP & 0.146968 & 0.024707 & 5.948376 & $0.0000 *$ \\
\hline SIZE & 0.006805 & 0.001008 & 6.747913 & $0.0000 *$ \\
\hline GDP & 0.077742 & 0.019216 & 4.045674 & $0.0001 *$ \\
\hline R-squared & 0.762759 & \multirow{4}{*}{\multicolumn{2}{|c|}{ Durbin-Watson stat }} & 1.695646 \\
\hline Adjusted R-squared & 0.728459 & & & \\
\hline F-statistic & 22.23791 & & & \\
\hline Prob(F-statistic) & 0.000000 & & & \\
\hline
\end{tabular}

* denote significance at $1 \%$ level.

Source: Financial statements of banks, MoFED reports and own computation 
Based on the above discussions, it can be concluded that the results obtained from the first (general) regression analysis were consistence with the result of the second regression analysis, which enhanced the reliability and validity of the data used in the model.

\section{Conclusions}

First, among all financial risks that were involved in this study, credit risk was the major factor that determines the variation of profitability in Ethiopian commercial banks under the period of consideration. The finding suggested a negative and statistically significant association with $1 \%$ significance level. This was in accordance with prior expectation and theory that suggested banks which fail to monitor their credit loans tend to be less profitable than those which pay particular attention to assets quality. In addition, the coefficient estimate of liquidity risk was also revealed a negative association with the profitability of Ethiopian commercial banks. The association was statistically significant at 1\% significance level. This indicated that, the existence of high liquidity risk may force banks to borrow emergency funds at excessive cost that can adversely affect their profitability.

Second, the coefficient estimate of interest rate risk and inflation were revealed a negative association with profitability of Ethiopian commercial banks. However, the coefficient estimates of the above mentioned variables were not statistically significant. Hence, interest rate risk and inflation were not a proper factor that determines the variation of profitability in Ethiopian commercial banks. Whereas, the coefficient estimates foreign exchange rate risk revealed a positive association with profitability of Ethiopian commercial banks but statistically was not significant. Therefore, foreign exchange rate risk was not found to be the major factor that determined the profitability of Ethiopian banks.

Third, among controlled variables, namely; bank size, capital strength and GDP growth were found to be the major factors determining the volatility of profit in Ethiopian commercial banks. The coefficient estimates of the above mentioned controlled variables were positive and statistically significant at $1 \%$ significance level. The magnitude of the coefficient estimate of capital was relatively high as compared to other variables, showing that an increase in capital strength will result in increased profitability. This is in line with the expectation as a bank with a sound capital position is able to pursue business opportunities more effectively and has more time and flexibility to deal with problems arising from unexpected losses, thus achieving increased profitability. The magnitude of the coefficient estimate of bank size was relatively small. This indicates that as larger banks of the country relatively experience more significant increases in profitability through economies of scale.

In addition to the financial risks that affect the profitability of Ethiopian banks, the interviewees also suggest that other factors like capital strength, size of banks and growth in GDP had a positive effect on the profitability of Ethiopian banks. On the other hand, other factors like, government regulations which imposed on private banks like the credit cap and the new regulation by the government require all commercial banks to purchase National Bank of Ethiopia bonds (contribution for the Great Renaissance Dam) worth $27 \%$ of their loan disbursements at a relatively minimum interest rate $(3 \%)$ which was even below the average $5 \%$ deposit rate paid by most of the privately owned banks for their depositors also considered as a factor that affects Ethiopian private banks profitability. Similar to the above factors absence of active secondary stock market and inflation were also considered as factors that affect Ethiopian banks profitability.

\section{Recommendations}

In line with the findings of the study, the following recommendations have been forwarded.

Both the results obtained from the regression analysis and the interview result suggested that, among all the risks that Ethiopian banks faced credit risk was the major factor that can adversely affect the profitability of Ethiopian banks. Therefore, Ethiopian banks should focus on credit risk management on the bases of maximizing return on its assets while keeping its credit exposure within acceptable limits. To do so, the bank should regularly review their credit portfolio quality, provisioning requirements, and customer exposure.

Liquidity risk was one of the factors that can affect the profitability of Ethiopian banks negatively since failure to properly manage liquidity can quickly result in significant unanticipated losses. Therefore, Ethiopian banks should have optimal level of liquidity which enables banks to meet their contractual commitments.

\section{References}

Abera, A 2012, 'Factors Affecting Profitability: An Empirical Study on Ethiopian Banking Industry', MSC thesis, Addis Ababa University, Ethiopia.

Akhtar, F M, Ali, K and Sadaqat, S 2011, 'Factors Influencing the Profitability of Conventional Banks of Pakistan', International Research Journal of Finance and Economics, Issue 66, pp117-124 $<$ http://www.eurojournals.com/finance.htm $>$ viewed in February 2102

Ali, K, Akhtar, MF \& Sadaqat, S 2011, 'Financial and Non-Financial Business Risk Perspectives - Empirical Evidence from Commercial Banks’, Middle Eastern Finance and Economics, pp.150-159. 
Al-Khouri, R 2011, 'Assessing the Risk and Performance of the GCC Banking Sector', International Research Journal of Finance and Economics, Issue 65, pp. 1450-2887

Ara, H, Bakaeva, M and Sun, J 2009, 'Credit risk management and profitability in commercial Banks in Sweden', MSc project, faculty of Business, Economics and law, university of Gothenburg

Athanasoglou, P, Brissimis, N S and Delis, D M 2005, 'Bank-specific, Industry specific and macroeconomic determinants of bank Profitability', bank of Greece, working paper, No. 25

Baesens, B and Gestel, VT 2009, 'Credit Risk Management: financial risk components, rating analysis, models, economic and regulatory capital', Oxford University Press Inc, New York

Brooks, C 2008, Introductory Econometrics for Finance, 2nd edn, Cambridge University Press, New York

Collier, P 2009, fundamentals of risk management for accountants and managers, 1st edn., Elsevier Ltd, Oxford, UK

Creswell, JW 2009, Research design: quantitative, qualitative and mixed methods approaches, 3rd edn, Sage Publications, California.

Damena, HB 2011, 'Determinants of commercial banks profitability: an empirical study on Ethiopian commercial banks', MSc project paper, Addis Ababa University.

Delport, S and Li, J 2009, 'A Study on Exchange Rate Exposure of Chinese Banks', school of economics and management, Lund university

Demerguc-Kunt A \& Huizinga H 1999 'Determinants of commercial bank interest margins \& profitability: some international evidence', World Bank Economic Review, vol. 13, pp.379-408

Fabozzi, J F, Mann V S and Choudhry, M 2003, Measuring and Controlling Interest Rate and Credit Risk, 2nd edn, John Wiley \& Sons, Inc, New Jersey, USA

Flamini, V, McDonald, C and Schumacher, L 2009, 'Determinants of commercial bank profitability in SubSaharan Africa', IMF Working Paper, pp. 1-30

Frederic, S 2004, The economics of money, banking, and financial markets, 7th edn, Pearson Addison Wesley press, Colombia

Gachua, F N 2011, 'the effect of foreign exchange exposure on a Firm's financial performance: a case of listed Companies in Kenya', working papers, KCA University, Kenya

Gandhi, G S2006, 'Selecting a Suitable Currency Options Hedging Strategy for Managing Foreign Exchange Risk', The Institute of Chartered Accountants of India

Gary, G 1995, 'banking theory and free banking history', journal of monetary economics, volume 16 no. 2

Guru B, Staunton J \& Balashanmugam B 2002, 'Determinants of commercial bank profitability in Malaysia', working paper, University of Multimedia

Hair JF, Black, WC, Babin, BJ, Anderson, RE \& Tatham, RL 2006, Multivariate data analysis, 6th edn, Pearson Education, New Jersey.

Imad, Z R, Qais, A K and Thair, A K 2011, 'Determinants of bank profitability: Evidence from Jordan', International Journal of academic Research, Vol. 3. No. 4 pp.180-191

Jaffe, W R 2003, Corporate Finance, 6th Edn, McGraw-Hill Companies Inc, United States of America

Jorion, P 2003, financial risk manager hand book, 2nd edition, John Wiley \& Sons, Inc., Hoboken, New Jersey

Kapur, D and Gualu, K A 2011, 'what drives the performance of commercial banks in Ethiopia?' International Journal of Research in Commerce \& Management, Vol. NO: 2

Kennedy, P 2008, Guide to econometrics, 6th edn, Blackwell Publishing, Malden.

Kithinji, A M 2010, 'Credit Risk Management and Profitability of Commercial Banks in Kenya', School of Business, University of Nairobi, Kenya

Kosmidou, K 2008, 'Determinants of bankse profits in Greece during the period of EU financial integration', Managerial Finance, vol. 34, no. 3, pp. 146-159

Li, Y 2007, 'Determinants of Banks' Profitability and its Implication on Risk Management Practices: Panel Evidence from the UK in the Period 1999-2006', MA thesis, the University of Nottingham

Miller, S M and Noulas, A G 1997, 'Portfolio Mix and Large-bank Profitability in the USA', Journal of Applied Economics, vol.29 (4), pp. 505-512

Motlagh, M, Abdekhodaee, S \& Ektesabi, R (2011), Efficiency, Effectiveness and Risk in Australian Banking Industry, World Review of Business Research, Vol. 1 No. 3, pp. 1-12

NBE 2009, 'Banking Industry Risk Management Survey Report', National Bank of Ethiopia, Addis Ababa, Ethiopia

NBE 2010/11, 'Annual report', National Bank of Ethiopia, Addis Ababa, Ethiopia

Olweny, T \& Shipo, MT 2011, 'Effects of banking sectoral factors on the profitability of commercial banks in Kenya', Economics and Finance Review, Vol. 1, no. 5, pp. 1-30

Pasiouras, F \& Kosmidou, K 2007, 'Factors influencing the profitability of domestic \& foreign commercial banks in European Union', Research in International Business and Finance, vol. 21, no. 2, pp. 222-237

Saunders, G and Cornett, J 2007, Financial Markets and Institutions; an Introduction to the Risk Management 
Approach, McGraw Hill Pub, New York

Shafiq, A and Nasr, M 2010, 'Risk Management Practices Followed by the Commercial Banks in Pakistan', International Review of Business Research Papers, Vol 6, Number, 2.Pp. 308 - 325

Shamsuddin, A 2009 'Interest rate and foreign exchange risk exposures of Australian banks: A note,' International Journal of Banking and Finance, Vol.6, Iss. 2

Shen, C, Chen, Y, Kao, F and Yeh, C 2009, 'Bank liquidity risk and performance', Journal of Financial Studies, Vol. 9, pp47-83

Tafri, H, Hamid, Z, Meera, M and Omar, A 2009, 'the Impact of Financial Risks on Profitability of Malaysian Commercial Banks: 1996-2005', International Journal of Social and Human Sciences 3, pp1672-1686

Tefera, T 2011, 'Credit Risk Management and Profitability of Commercial Banks in Ethiopia', MSc thesis, Faculty of Business and Economics, Addis Ababa University, Ethiopia

Tesfaye, T 2012, 'determinants of liquidity of Commercial Banks in Ethiopia', MSc thesis, Faculty of Business and Economics, Addis Ababa University, Ethiopia

Valentina, F, Calvin, M and Liliana, S 2009, 'The Determinants of Commercial Bank Profitability in SubSaharan Africa', IMF Working Paper, WP/09/15

Wang, H, Yan, J and Yu, J 2012, 'Prospect Theory and the Risk-Return Tradeoff', IBA Bulletin, Special Issue, University of Minnesota, New York 